Click www.researchjournal.co.in/online/subdetail.html to purchase.

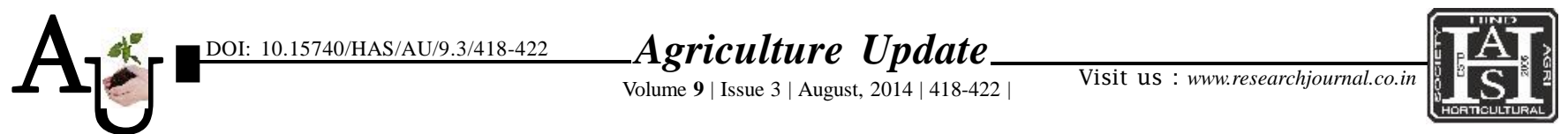

e ISSN-0976-6847

Research Article

\title{
Adoption of recommended package of practices by green gram growers
}

\author{
R.P. KADAM, S.M. UMATE, G.S. PAWAR AND A.S. LAD
}

Article Chronicle： Summary : The present study was conducted in Parbhani district of Marathwada region of Maharashtra state. Received : 01.07.2014;

Revised : 10.07.2014; Accepted :

19.07.2014 Parbhani, Jintur and Selu talukas of Parbhani District were purposively selected for study. 40 respondents from each taluka on the basis of maximum area under green gram. Thus, a total of 120 respondents were selected as sample for this study. The respondents were interviewed with the help of well structured interview schedule. Majority of the green gram were from medium farming experience, middle school level of education, medium land holding, joint family type and medium extension contact, social participation, annual income, economic motivation, risk orientation, sources of information, market orientation with medium knowledge level of recommended package of practices of green gram. It is also observed that education, extension contact, social participation, annual income, economic motivation, risk orientation, sources of information, were positively and significantly related with the level of knowledge of recommended package of practices of green gram growers.

How to cite this article : Kadam, R.P., Umate, S.M., Pawar, G.S. and Lad, A.S. (2014). Adoption of recommended package of practices by green gram growers. Agric. Update, 9(3): 418-422.

\section{KeY WoRdS:}

Adoption, Recommended practices, Green gram growers 